\title{
Analysis of Solid Waste Management and Greenhouse Gas Emissions in México: A Study Case in the Central Region
}

\author{
María Luisa Castrejón-Godínez¹, Enrique Sánchez-Salinas² , Alexis Rodríguez², \\ Ma. Laura Ortiz-Hernández ${ }^{1,2 *}$ \\ ${ }^{1}$ Programa de Gestión Ambiental Universitario, Cuernavaca, México \\ ${ }^{2}$ Centro de Investigación en Biotecnología, Universidad Autónoma del Estado de Morelos, Cuernavaca, México \\ Email: *ortizhl@uaem.mx
}

Received 27 January 2015; accepted 13 February 2015; published 25 February 2015

Copyright (C) 2015 by authors and Scientific Research Publishing Inc.

This work is licensed under the Creative Commons Attribution International License (CC BY).

http://creativecommons.org/licenses/by/4.0/

(c) (i) Open Access

\section{Abstract}

In this work, an analysis of the generation, composition and management of the urban solid waste in Mexico and its relation to greenhouse gas emissions is described; as well a case study in Morelos, a state in the central region of the country. Data were collected from the scientific literature and existing data bases at state and national levels. In addition, the emissions of greenhouse gas were calculated for a period of 14 years, using the Intergovernmental Panel on Climate Change (IPCC) methodology. The municipal solid waste data collected from 1998 to 2012 reveal an increase in the amount of waste generated in Mexico and in Morelos (38\% and 43\%, respectively), which have been influenced by the urbanization process and the population increase. According to the official data, the composition of the urban solid waste in Mexico, is mostly organic matter (50\%), represented by food and garden residues, as well as paper and cardboard (near to 14\%). While in Morelos, the percentages of generation for these materials are $44 \%$ and $9 \%$, respectively. The management of the urban waste mainly consists of house collection, principally in metropolitan zones and medium and small cities, representing $78.7 \%$ in Mexico and $89.2 \%$ in Morelos. The second way to eliminate the solid wastes is open burning (mostly in semi-urban and rural areas), representing $14.5 \%$ and $6.7 \%$ for Mexico and Morelos, respectively. During this period, the nationwide greenhouse gas emissions derived from solid waste management (SWM) increased by $180 \%$, while in Morelos, an increase of $42.5 \%$ was calculated. Thus, the population increment and urbanization process were correlated with the rise in the amount of residues generated in Mexico and Morelos.

\footnotetext{
*Corresponding author.
} 


\section{Keywords}

\section{Greenhouse Gas Emissions from Waste, Methane, Solid Waste Management, Mexico}

\section{Introduction}

Rapid population growth and changes in consumption habits have caused a considerable increase in solid waste production, and the amounts of refuse destined for final disposal have rapidly consumed landfill capacity. Cities in Mexico, like many other cities in developing countries, face serious environmental pollution problems caused mainly by the inadequate and inefficient final disposal of their solid and liquid waste [1]. Historically, Mexico is faced with serious environmental and administrative challenges with respect to solid waste management (SWM), where the public sanitation system lacks adequate planning and has an unsustainable SWM [2]. In Mexico, the municipal governments are responsible for the SWM, and therefore, SWM improvements must be implemented by the municipality.

Municipal solid wastes (MSW) include non-hazardous wastes generated in households, commercial establishments, institutions, and non-process-related industrial wastes (e.g., waste paper and paperboard); it excludes wastes from municipal services such as water and wastewater treatment sludge, industrial process wastes, agricultural wastes, and mining wastes [3].

With rapid economic growth and massive urbanization, Mexico faces the problem of MSW generation, collection, transport, disposal and management. These problems are caused by technical, financial, institutional, economic and social factors that constrain the development of effective SWM systems. Another major problem with the disposal sites is their proximity to residential or agricultural areas. Most waste is dumped on open land and in natural and engineered drains, thus contaminating groundwater in the rural areas by infiltration and blocking the flow of storm water in cities [2]. The inadequate disposal of this waste creates a strong negative environmental impact on soil, groundwater, surrounding flora and fauna, and public health [4]. The composition of solid waste is affected by different factors such as a seasonal variation in consumption and modification of consumption patterns due to economic and demographic changes experienced in the country [5] [6].

Once deposited in a landfill or open dump, the carbon in waste containing organic materials, such as food, paper, wood, and garden trimmings, is consumed by microorganisms, causing decomposition. Under the anaerobic conditions prevalent in such sites, the microbial communities contain methane-producing bacteria. Because the microorganisms gradually decompose organic matter over time, methane $\left(\mathrm{CH}_{4}\right)$, carbon dioxide $\left(\mathrm{CO}_{2}\right)$, and other trace amounts of gaseous compounds are generated and form landfill gas. $\mathrm{CH}_{4}$ and $\mathrm{CO}_{2}$ are greenhouse gas (GHG), whose presence in the atmosphere contributes to global warming and climate change. $\mathrm{CH}_{4}$ is a particularly potent GHG and is currently considered to have a global warming potential 28 times (over a 100-y observation period) that of $\mathrm{CO}_{2}$ [7].

The objective of this study was to analyse the current management of MSW in Mexico and its contribution to the generation of GHG, using a state in central Mexico as a case study.

\section{Study Area}

Mexico is located between the latitudes of $14^{\circ} 32^{\prime} \mathrm{N}$ and $32^{\circ} 43^{\prime} \mathrm{N}$ and longitudes of $86^{\circ} 42^{\prime} \mathrm{W}$ and $118^{\circ} 27^{\prime} \mathrm{W}$ (Figure 1). Morelos is a state located in the central region of Mexico, occupying an area of $4879 \mathrm{~km}^{2}$, which represents only $0.25 \%$ of the territory of Mexico. Morelos consists of 33 municipalities, each with an autonomous government.

Morelos has a total population of $1,777,000$ inhabitants, corresponding to $1.58 \%$ of the total population in Mexico (112,336,538 inhabitants), with an average annual growth rate of $2 \%$, which is higher than the national average (1.8\%). Its population density is high (364 inhabitants per $\mathrm{km}^{2}$ ) compared to the national average (57 inhabitants per $\mathrm{km}^{2}$ ), representing the third highest density in the nation.

\section{Methodology}

\subsection{Generation and Composition of MSW}

For data on the generation and composition of MSW in Mexico and Morelos, as well as other social data, dif- 


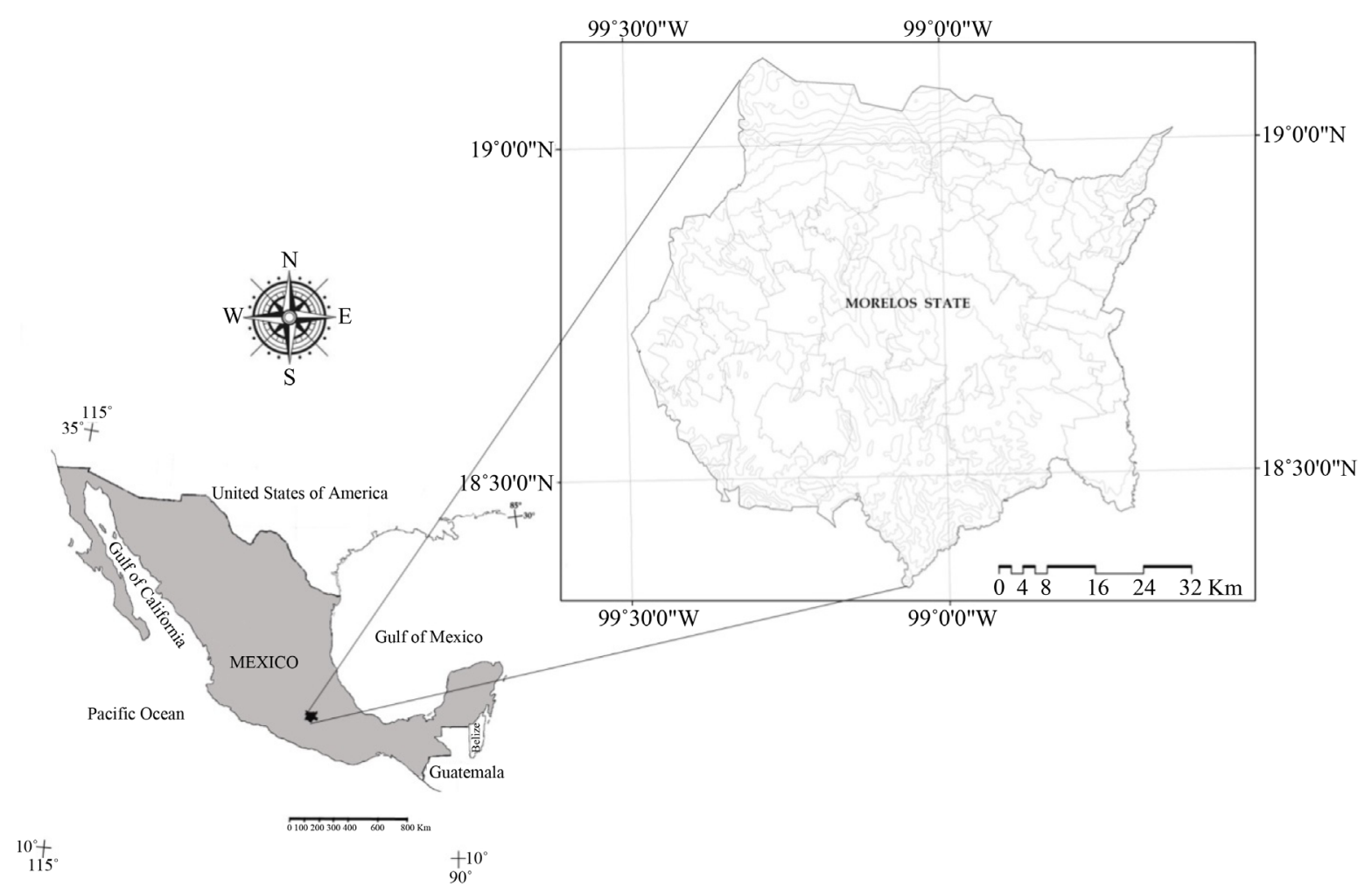

Figure 1. Location of Mexico and Morelos state.

ferent sources were consulted. The overall population of the state of Morelos was obtained from the information available in the population national census for 2000, 2005 and 2010; the population data for prior and later years were calculated according to the population growth rate [8] [9]. The total urban solid waste generation for the 1998-2012 period was reported in thousand tons. These values were obtained by a query of the thematic module environmental dimension section on urban solid waste generation for the state in the National System of Environmental and Natural Resources database [10]. Additionally, the fraction of the population covered by the MSW collection service for the 1998-2012 period was obtained from the same database. The corresponding data on waste composition and the number, surface and capacity of the landfills installed in Morelos, available for 2012, were obtained from the National Institute of Geography and Statistics (INEGI for its acronym in Spanish) in its Statistics for Environment, Human Activities and Solid Waste section.

\subsection{Management of Municipal Solid Waste}

For the management of MSW, we consulted the current official reports, in addition to direct informal interviews with officials of SWM in the different municipalities. The amount of municipal solid waste disposed in landfills was obtained from the database of the National System of Environmental and Natural Resources [10] thematic environmental dimension module.

\subsection{Greenhouse Gas Emission from Municipal Solid Waste in Mexico and Morelos}

Data on the national methane emissions in Mexico were obtained from the fifth communication to the United Nations Framework Convention on Climate Change (UNFCCC) [11]. Regarding the GHG emissions for Morelos in this study, the GHG annual contributions derived from the SWM in the state of Morelos for the 1998-2012 period were estimated utilizing module 6 of the International Panel on Climate Change [12], provided by the UNFCCC. The information on the amount of urban solid waste was utilized to calculate the $\mathrm{CH}_{4}$ emission rates and convert them to equivalent $\mathrm{CO}_{2}$ units. All of these calculations were made in Microsoft Excel 2003 spreadsheets according to the IPCC guidelines [13]. 
The completeness grade and quality of the SWM available information for the state of Morelos were limited; additionally, specific emission factors for Mexico do not exist. For these reasons, the contribution of this subcategory to the total amount of GHG was calculated using a Tier 1 methodology. The default values of 0.8 for the methane correction factor, 0.16 for the degradable organic carbon fraction, 0.5 for the fraction of carbon released as methane and zero for both methane oxidation factor and recovery (R) were used [14]. These last values were used because no $\mathrm{CH}_{4}$ recuperation process is realized in the state $(\mathrm{R}=0)$ and according to the IPCC guidelines, the value of the methane oxidation factor $(\mathrm{OX})$ is zero when the country specific information is not available for the study.

The $\mathrm{CH}_{4}$ emissions from municipal solid waste were estimated according to IPCC Good Practice Guidance [12], applying the following equation:

$$
\mathrm{CH}_{4} \text { emissions }(\mathrm{Gg} / \mathrm{yr})=\left[\left(\mathrm{MSW}_{\mathrm{T}} \times \mathrm{MSW}_{\mathrm{F}} \times \mathrm{L}_{0}\right)-\mathrm{R}\right] \times(1-\mathrm{OX})
$$

where:

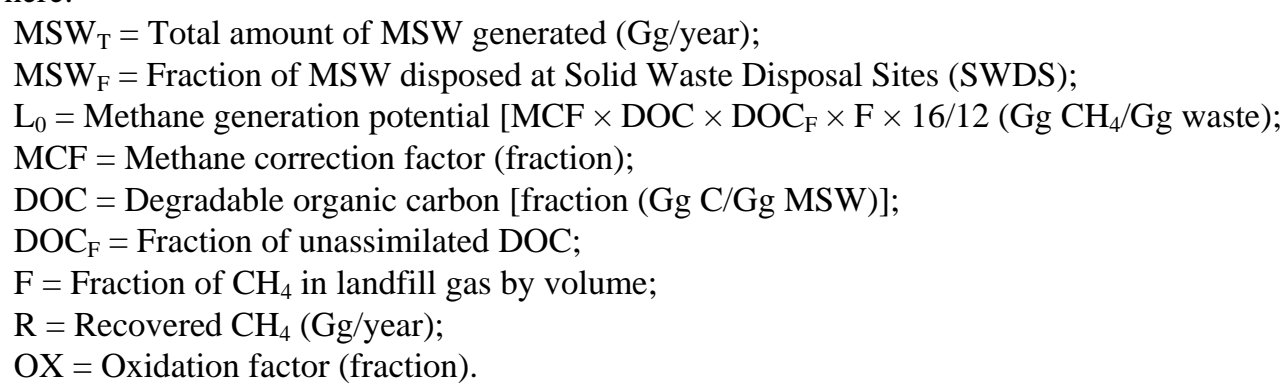

\section{Results and Discussion}

\subsection{Municipal Solid Waste Generation and Composition}

The data obtained for the 1998-2012 period provide the amount of municipal solid waste generated in Mexico and Morelos, as well as the calculated per capita daily MSW generation, which are shown in Figure 2. According to the Mexican Secretary of Environment and Natural Resources (SEMARNAT, for its acronym in Spanish), the total MSW generation in Mexico increased from 30.5 million tons in 1998 to 42.1 million tons in 2012, a $38 \%$ increase in 14 years at a growth rate of $2.7 \%$. The per capita MSW generation has ranged from 0.85 to 0.99 $\mathrm{kg} / \mathrm{inh}$ abitant/day in the same period. MSW are mainly produced in the central region (50\%), followed by the North region (18\%) and Mexico City (13\%).

Regarding the state of Morelos, MSW generation has increased by approximately 43\% in the same period, from 0.44 to 0.63 million tons [10]. This increment in MSW could be related to population growth (approximately 23\%), industrial development, technological changes, consumption pattern changes and migration from rural areas to cities. With respect to the per capita daily MSW generation, as shown in Figure 2, in the 19982003 period, each inhabitant of Morelos generated approximately $0.8 \mathrm{~kg}$ of waste. However, from 2005 to 2012 , this value increased to more than $0.9 \mathrm{~kg}$ of waste. The 100-gram increase in the MSW observed in 2012 with respect to the per capita value reported in the year 1998 represents the generation of an additional 515.8 tons per day.

The rate of solid waste generation is intrinsically related to urbanization, industrialization and economic development. The quantity of solid waste generation is mostly associated with the economic status of a society, [15] suggests that the quantity of solid waste generation is lower in countries with lower gross domestic product (GDP). In México and Morelos, there is a direct correlation between the increase in GDP and the increase in MSW generation reported for the state of Morelos (data no shown) [16]. The per capita waste generation rates in many developing countries have now crossed the one kilogram per day mark. In most OECD countries, municipal solid waste generation rates are slightly above one kilogram per capita [17].

In Mexico, the MSW have a high proportion of organic materials, which are those formed by food waste and plant material resulting from the maintenance of parks and gardens. MSW composition is followed by those residues that are not valued, in addition to paper, metals, plastics and textiles. Figure 3 shows a comparison of the MSW composition in Mexico for 1998 and 2012. As shown, an increase in plastics use was identified.

According to the State Commission of Water and Environment [18], the MSW generated in Morelos are 


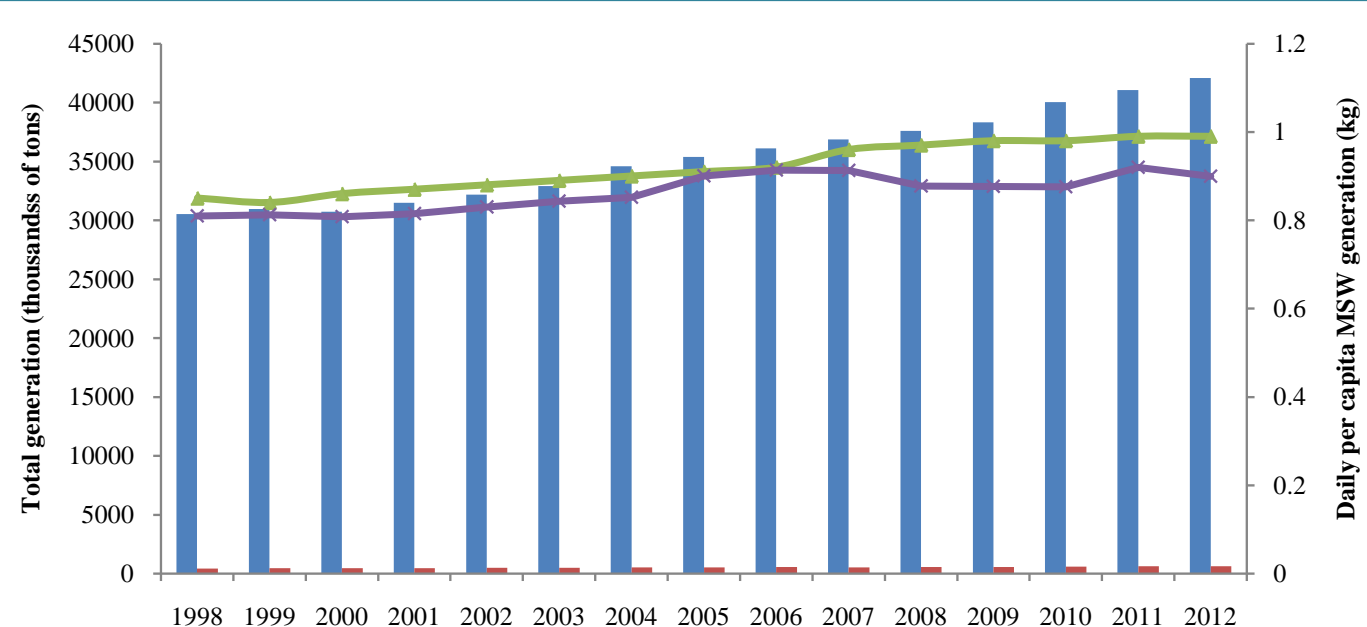

Year

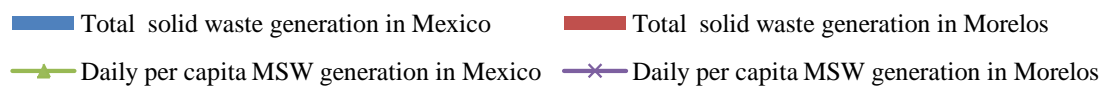

Figure 2. Total urban solid waste generation and daily per capita MSW generation for the period 19982012 in Mexico and in the state of Morelos.

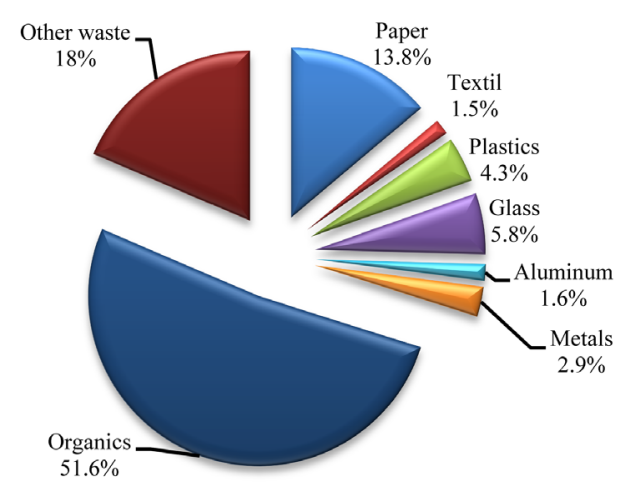

(a)

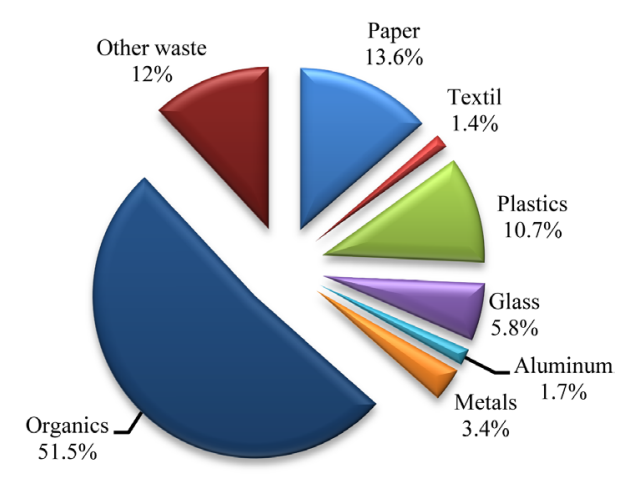

(b)

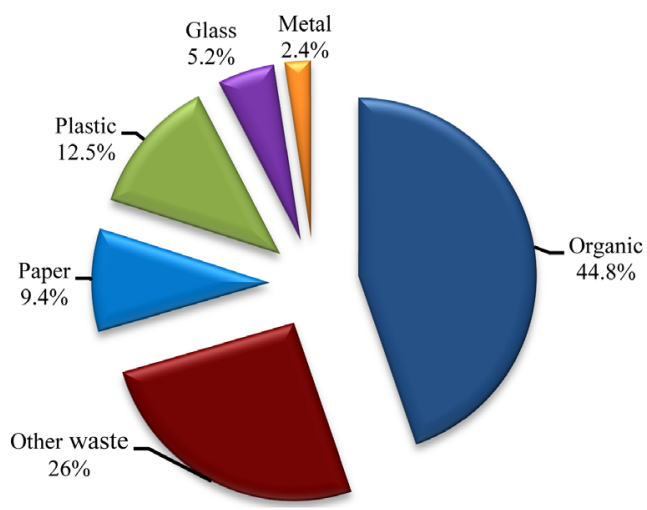

(c)

Figure 3. Composition of MSW in Mexico and Morelos. (a) Mexico 1998; (b) Mexico 2012 and (c) Morelos. Organic include: food and garden residues; paper include: paperboard and other paper materials; metal include: iron, copper, lead, tin and nickel; and other waste include: fine debris, disposable diapers, etc. [10]. Data for Morelos refer to the year 2007 and since then there is no data on its composition [18]. 
composed mostly of organic waste as food and garden residues (approximately 50\%), waste that, according to reported data, are recovered or recycled at a very low percentage. Although paper is an organic material, it is not included in the category of organic waste because this type of residue is capable of being valued through recycling [19]. It was also reported that of the total composition of the MSW, $12.5 \%$ is plastic materials, $9.4 \%$ corresponds to paper, $5.2 \%$ is glass and $2.4 \%$ represents metals (Figure 3 ).

\subsection{Management of Municipal Solid Wastes}

The management of MSW comprises its collection, transportation, storage, selection and final disposition.

\subsubsection{Collection}

According to the 2010 national census, 28,643,491 habited households were reported in Mexico, while in the state of Morelos, 475,166 households were registered. These houses could be located in metropolitan zones, medium and small cities, and semi-urban or rural areas. The people who live in these houses produce waste at different proportions, and the generated quantity adjusts according to their income and location. There are many ways to eliminate these wastes, including home collection by the municipal service, directly disposition in containers, deposits or public dumps by people, open burning or burying of waste in the field, or disposal without any control in wastelands fields, streets, natural depressions, rivers, lakes or in the sea.

According to the information generated by INEGI, through a series of surveys, in the year 2012, the wastes that were generated in the 28.6 million occupied homes in Mexico were disposed in the following ways [20]. As shown in Figure 4, in both Mexico and Morelos, the main method for the elimination of solid wastes is house
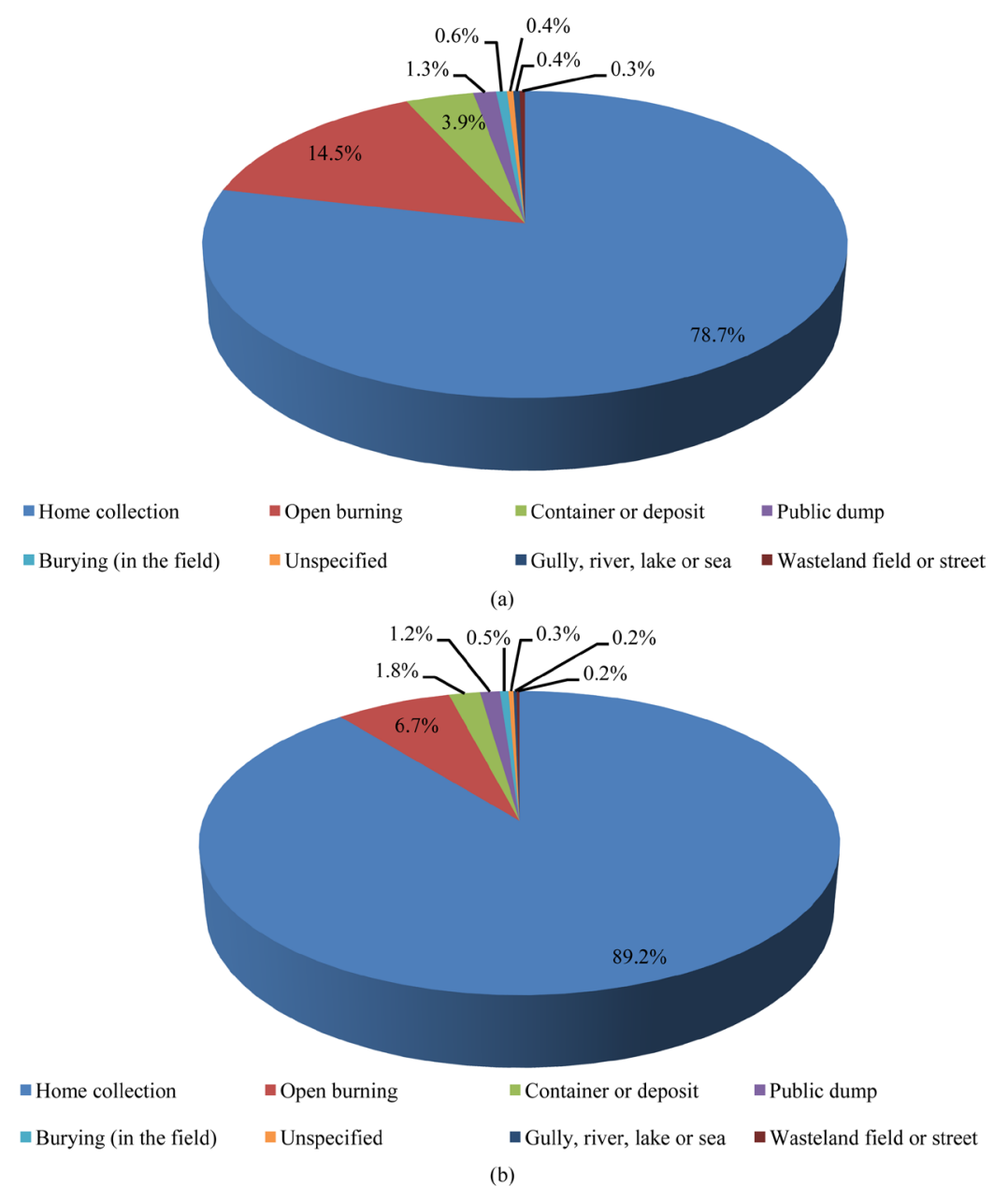

Figure 4. Main ways of MSW disposing in households (a) Mexico and (b) Morelos [20]. 
collection (mainly in metropolitan zones and medium and small cities), representing $78.7 \%$ and $89.2 \%$, respectively. The second way to eliminate the solid wastes is open burning (in semi-urban and rural areas), representing $14.5 \%$ and $6.7 \%$, respectively. All other elimination methods show similar proportions for both the national and the state level [20].

One of the most important aspects of adequate management of MSW is the waste collection [21]. In Mexico, a daily average of 86,343 tons of MSW is collected, which are mainly generated in homes, parks, gardens and public buildings. In Morelos, approximately 1.2 million people in 1998 were benefited with the collection service, a number that increased to nearly 1.7 million people by the year 2012, covering $90.7 \%$ of the total population. In Morelos, 971 tons/day and 1564 ton/day of MSW were collected for the years 1998 and 2012, respectively (Figure 5).

However, in Mexico the waste collection is generally not performed differentially. In 2010, 89\% of the waste collected was non-selective and the remaining $11 \%$ was selective (i.e., separation of MSW into organic and inorganic, at the very least). Thereby, in most cases, mixed wastes (garbage) are directly transported to a landfill for their final disposal [22]. In the Morelos state for the year 2012 only four municipalities reported information about the selective waste collection, which represents only the $9.14 \%$ of the total area of the state [20].

\subsubsection{Solid Wastes Recovery for Recycling}

Unfortunately, most homes in Mexico and in Morelos lack the discipline to separate generated waste; the proportion of households in which the waste is separated is low. The common practice is to have a single container where mixed wastes (organic and inorganic) are stored, and at least two days a week, these wastes are given to a truck that provides this collection service for the municipality. However, as was mentioned above, only a small proportion of the MSW are collected differentially and recycled. Wastes that are recovered for recycling may come from different sources, such as from separation in households which can then be delivered to waste-collection sites, from collection vehicles, from places established for waste segregation after collection, and from final disposal sites, where separation is conducted by waste pickers who work informally in such sites.

Although the volume of MSW that is recycled in the country has increased in recent years, it remains low. According to the amounts obtained on disposal sites, in 2011, 4.8\% of the volume of MSW generated was recycled. However, this percentage could reach $10 \%$ because much of the MSW with potential to be recycled is recovered before reaching the final disposal sites. The recycled wastes in Mexico (2012) consisted of paper, cardboard and paper products (143,187 kg/day), followed by others non-specified (74,364 kg/day), PET (70,798

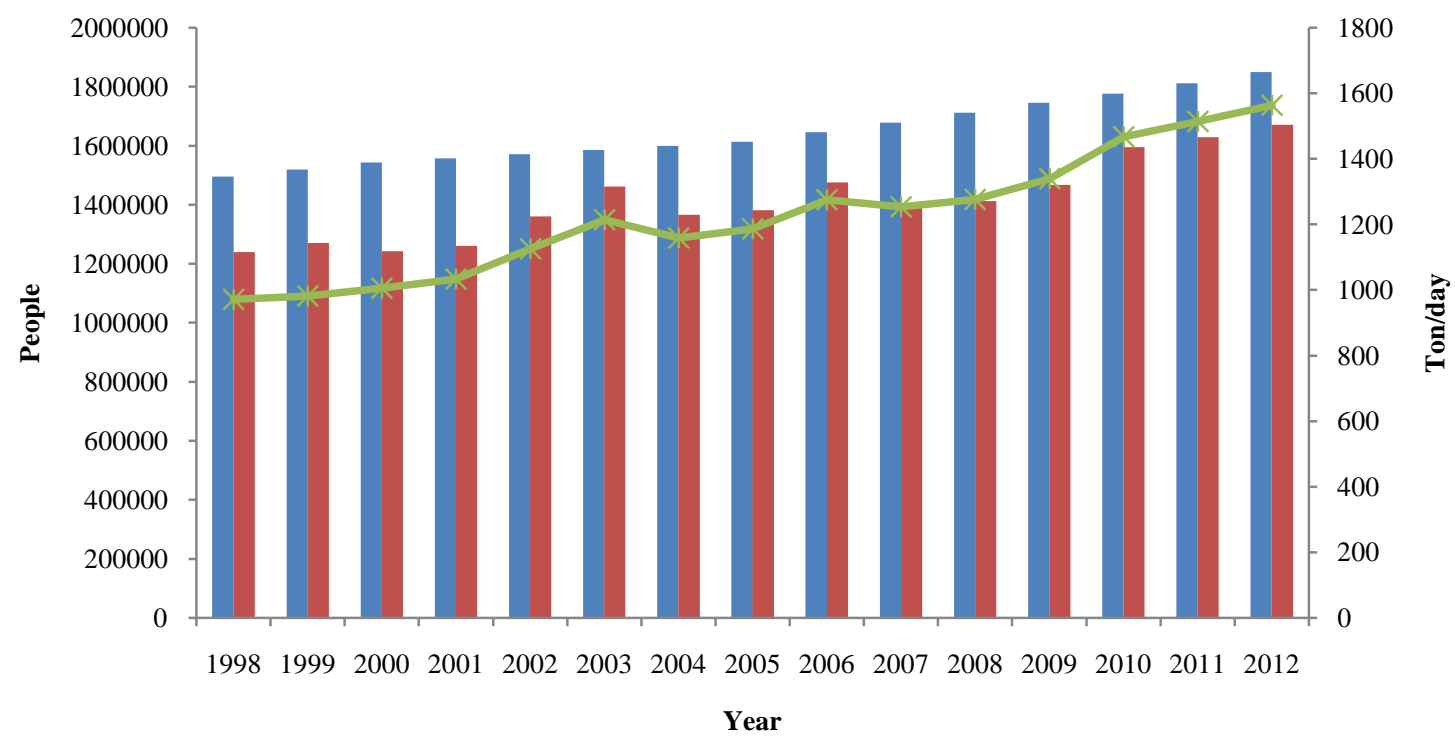

Total population Population benefitting from the collection service — $\quad$ Ton/day

Figure 5. Total population and the population covered by the MSW collection service of the state of Morelos for the period 1998-2012. The amount of MSW collected daily, is also shown. 
kg/day), glass (62,052 kg/day), plastics (41,115 kg/day), electronics (22,842 kg/day), metals (21,868 kg/day), aluminium and copper (6129 kg/day), bronze and lead (5710 kg/day). Meanwhile in Morelos, the recycled wastes (2012) consisted of paper, cardboard and paper products (102 kg/day), followed by glass (80 kg/day), plastics and PET (24 and $23 \mathrm{~kg}$ /day, respectively), metals (23 kg/day), electronics (3 kg/day) and others nonspecified (9 kg/day) (Figure 6). The recyclable materials mixed with other materials contained in the no differentially collected wastes, are delivered to the waste-collection sites, where waste pickers could receive financial compensation in return for their recovery and sell. Subsequently, the people responsible for these collection centres transfer the waste to recycling companies [22].

\subsubsection{Transport}

Wastes that are collected are transported to a transfer centre (Figure 7), where trucks with greater volume ca-

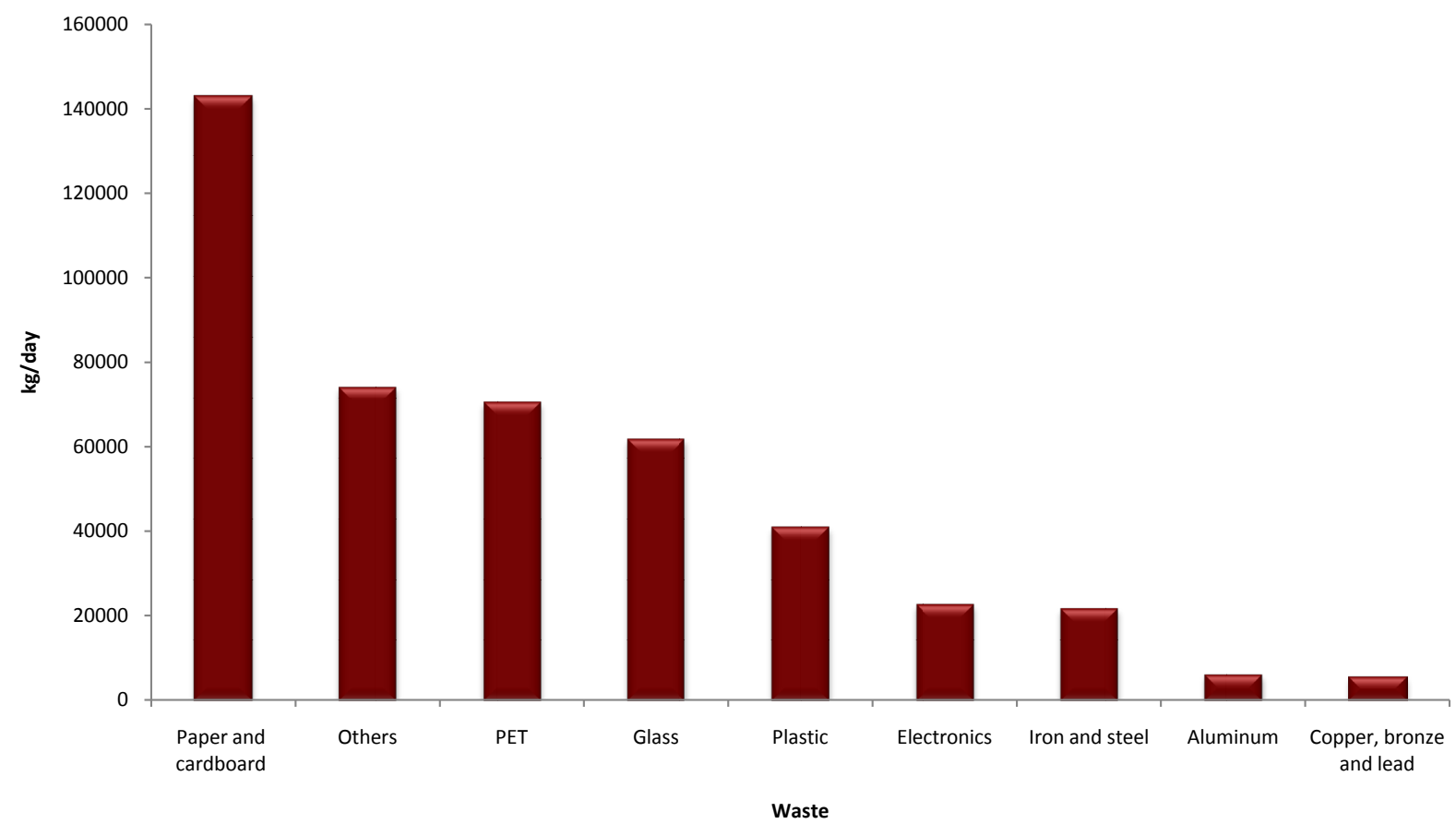

(a)

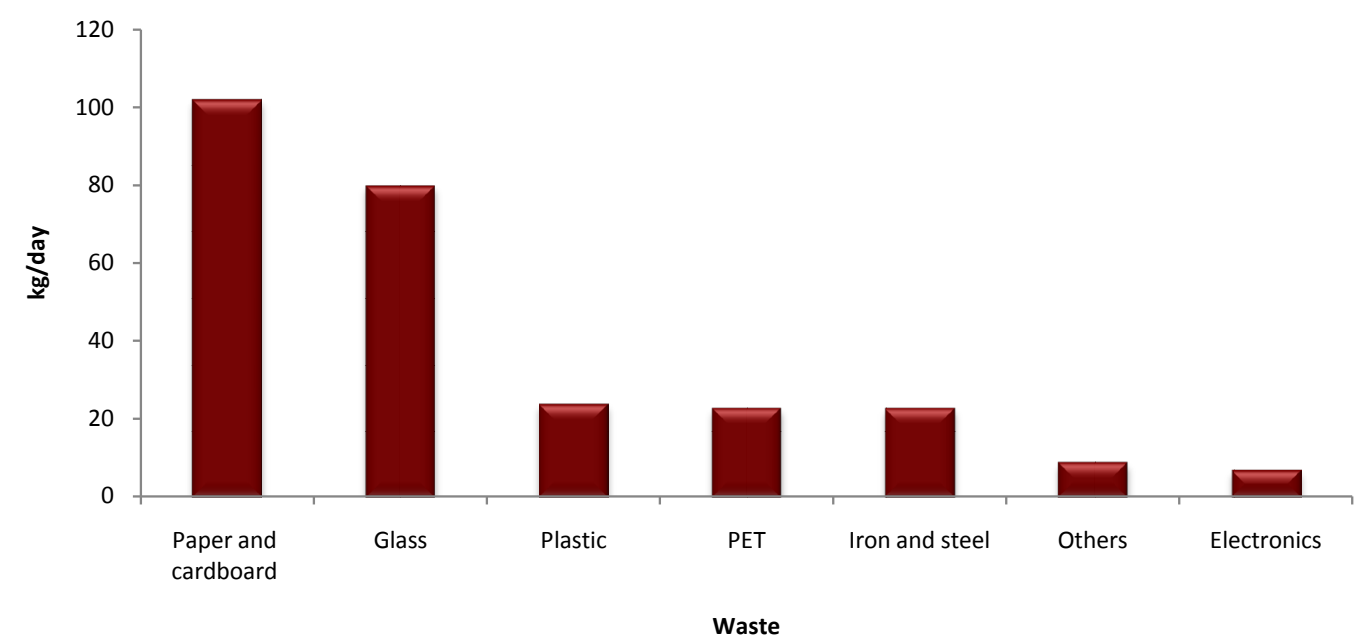

(b)

Figure 6. Waste collected by type of material (daily average during 2012, kg/day). (a) Mexico and (b) Morelos. It can be seen that in Morelos are not collected the same types of waste nationally. 


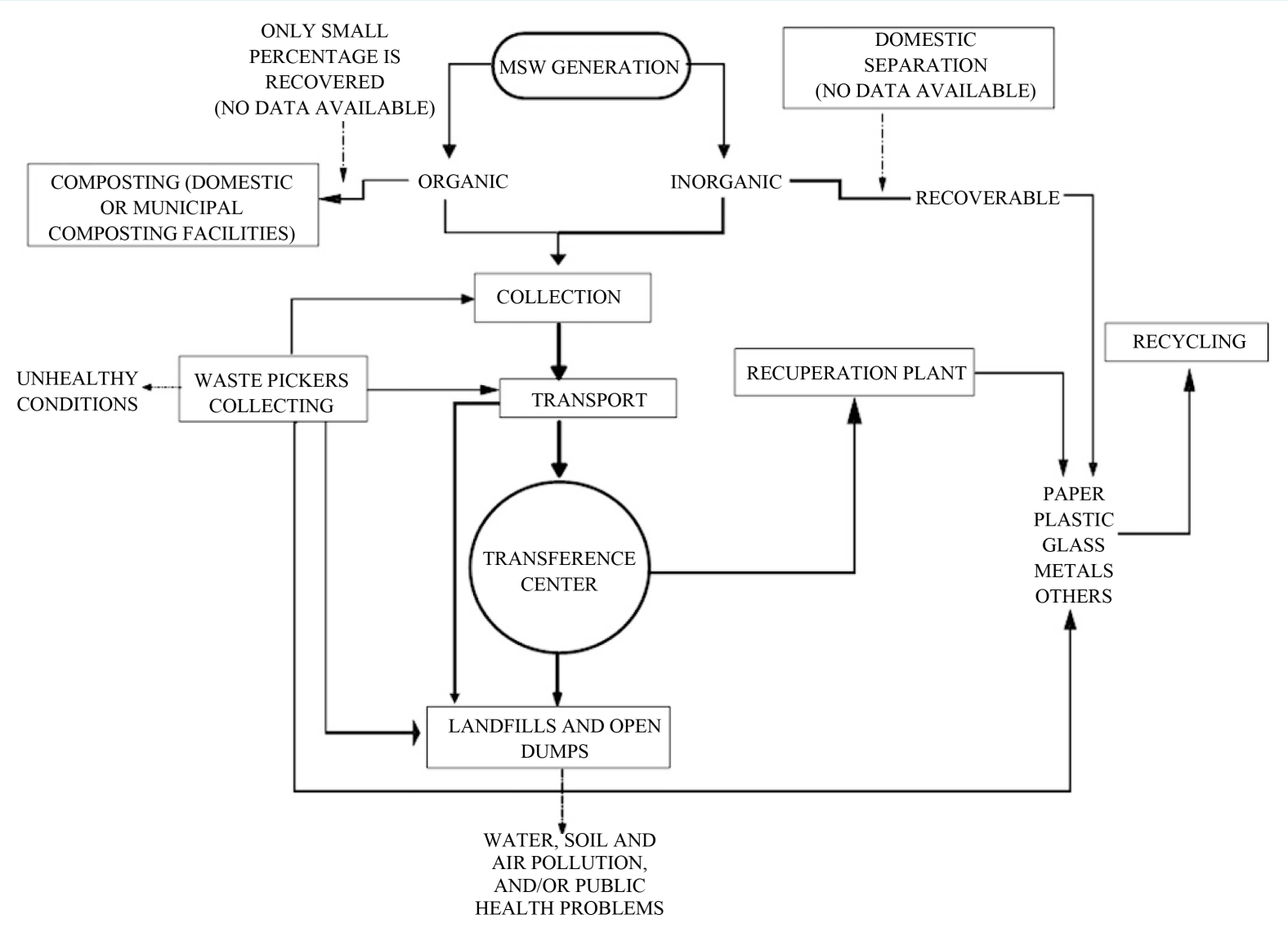

Figure 7. Generalized municipal SWM process in Mexico and Morelos.

pacities are filled with garbage, and the wastes are then sent to landfills for final disposition.

\subsubsection{Final Disposal}

The final disposal indicates the permanent deposit of waste at a site. Due to the negative health and environmental impacts affecting the quality of life and social welfare, it may be appropriate to prevent damage in ecosystems. The Mexican regulation establish the specifications for the environmental protection, the site selection, design, built, operation, monitoring, closing and the complementary work realized in a waste final disposal site. According with this regulation, all landfills have to accomplish with the next minimal requirements: All disposal sites should have a natural geological barrier or equivalent to a thickness of one meter and a coefficient of hydraulic conductivity of at least $1 \times 10^{-7} \mathrm{~cm} / \mathrm{sec}$ on the area for the establishment of cells disposal; or, guarantee it with a system of equivalent waterproofing. The wastes have to be compacted $\left(300 \mathrm{~kg} / \mathrm{m}^{3}\right) \mathrm{y}$ covered at least once a week; the entrance of dangerous waste must to be avoided, vermins must to be controlled and the entrance of other animals must to be avoided; all the final disposition site have to be fenced [23].

The final disposal of MSW is characterized by the use of traditional processes and systems; thereby, at a national level, landfills and dumps with different degrees of control can coexist. In this last case, waste undergoes biodegradation, which would allow the subsequent use of some by-products (biogas) and the subsequent reuse of the site as suitable ground for parks or recreational areas [1]. Specifically in Morelos, the final disposal of MSW occurs in sites with different characteristics such as four landfills/controlled sites and 14 open dumps [20]; this pattern is a clear example of the management usually conducted in Mexico.

The final disposal of municipal solid waste in landfills or open dumps results in inevitable consequences such as gas and leachate generation, primarily due to microbial decomposition, climatic conditions and landfilling operations. The migration of gas and leachate away from the landfill boundaries and their release into the surrounding environment present serious environmental concerns at both existing and new facilities. In addition to potential health hazards, these concerns include and are not limited to fires and explosions, vegetation damage, unpleasant odours, landfill settlement, ground water pollution, air pollution and global warming [24] [25]. 


\subsection{Global Analysis of Waste Management}

Adequate processing of wastes is still an unsolved task in Mexico and in Morelos. At the municipal level, limited knowledge of technologies and good practices for waste management, lack of equipment for the collection of sorted materials and the absence of decision makers interested in environmental issues hamper the development of waste-separation programs. Awareness campaigns influence the behaviour of individuals to segregate waste due to their environmental concerns and the need to participate in solutions. The livelihoods of many poor people depend on collecting recyclable materials from door to door, on the streets or at the disposal site. Recycling companies have appeared in cities due to the increase in the prices of these secondary materials. The combination of these two facts seems to have promoted more separation at the household level. Finally, separation is improved when citizens share responsibility with the municipality for the decision-making regarding the waste system of the city [26]. In Morelos, as in other Mexican states, the municipalities control the generated MSW, and they must implement the necessary measures to give people urban cleaning services and ensure the proper management of scanning services, collection, transfer, transportation, treatment and disposal of MSW, in addition to increasing the awareness and training of the population (Figure 7) [27]-[29].

Morelos has serious environmental challenges concerning MSW management. Just as in other states in Mexico, the public sanitation system lacks adequate planning, and the MSW management is unsustainable. For example, only a small portion of the organic waste from MSW is treated in a composting process, which is limited to two municipalities plus some individual efforts of people who compost their own waste. Unfortunately, data on the waste proportion that is composted do not exist. All of these wastes have great potential to be recycled through a composting process in which a substrate rich in nutrients (humus) that could be used as a substrate for growing plants or for restoring soils degraded by different processes (erosion, pollution, etc.) is obtained. Composting the organic portion of the MSW of Morelos, in addition to the recovery of wastes, could help to significantly reduce the total amount of waste and diminish their effect on the release of GHG into the atmosphere.

\subsection{GHG Emissions from Municipal Solid Wastes}

The national GHG emission values from waste, were obtained from INECC-SEMARNAT (2012) [11], while the Morelos GHG emission values were calculated in this work applying the Equation (1). As shown in Table 1, the GHG emissions for MSW in Mexico had increased from $7905.7 \mathrm{Gg} \mathrm{CO}_{2}$ eq in 1998 to $22117.7 \mathrm{Gg} \mathrm{CO}_{2}$ eq

Table 1. Emissions of $\mathrm{CH}_{4}$ and $\mathrm{CO}_{2}$ eq from municipal solid waste in the state of Morelos and Mexico, period 1998-2010.

\begin{tabular}{|c|c|c|c|c|}
\hline \multirow{3}{*}{ Year } & \multicolumn{4}{|c|}{ Solid waste emissions (Gg) } \\
\hline & \multicolumn{2}{|c|}{ Morelos $^{\S}$} & \multicolumn{2}{|c|}{$\operatorname{Mexico}^{\dagger}$} \\
\hline & $\mathrm{CH}_{4}$ & $\mathrm{CO}_{2} \mathrm{eq}$ & $\mathrm{CH}_{4}$ & $\mathrm{CO}_{2}$ eq \\
\hline 1998 & 29.1 & 611.6 & 376.5 & 7905.7 \\
\hline 1999 & 29.4 & 617.9 & 448.0 & 9406.9 \\
\hline 2000 & 30.2 & 633.1 & 507.5 & 10658.3 \\
\hline 2001 & 31.0 & 650.9 & 558.8 & 11734.7 \\
\hline 2002 & 31.8 & 666.8 & 615.0 & 12915.4 \\
\hline 2003 & 32.4 & 679.9 & 665.9 & 13983.3 \\
\hline 2004 & 34.6 & 725.8 & 721.7 & 15156.1 \\
\hline 2005 & 35.4 & 742.4 & 774.0 & 16253.1 \\
\hline 2006 & 36.0 & 756.2 & 822.9 & 17280.9 \\
\hline 2007 & 35.4 & 742.4 & 871.6 & 18303.5 \\
\hline 2008 & 36.0 & 756.2 & 930.3 & 19535.4 \\
\hline 2009 & 36.7 & 770.0 & 992.9 & 20851.3 \\
\hline 2010 & 39.2 & 822.4 & $1,053.2$ & 22117.7 \\
\hline 2011 & 40.4 & 848.6 & - & - \\
\hline 2012 & 41.5 & 871.3 & - & - \\
\hline
\end{tabular}

${ }^{\S}$ This work (calculated applying Equation (1)); ${ }^{\dagger}$ INECC-SEMARNAT, 2012, information not available. 
in 2010, representing an increase of 180\%. In Morelos, 611.6 and $871.3 \mathrm{Gg} \mathrm{CO}_{2}$ eqwere emitted in 1998 and 2012, respectively, representing an increase of $42.5 \%$ for the period. This emission profile could be related mainly to the global society's consumerist lifestyle, which promotes irrational exploitation of natural resources and the production of goods that meet our needs, resulting in the increased waste volume arriving at the statedisposal sites.

In Morelos the only inventory published reporting the total anthropogenic GHG emissions, has been made for the 2005-2009 period. For the year 2009, a total of $8335.83 \mathrm{Gg} \mathrm{CO}_{2}$ eq were emitted [30], and the emissions from MSW correspond to 9.2\% (770.0 Gg de $\mathrm{CO}_{2}$ eq). By contrast, in Mexico for the same year, GHG emissions from MSW management was $20851.3 \mathrm{Gg} \mathrm{CO}_{2}$ eq, representing 2.8\% of total emissions [11]. This difference in the emission proportion is probably due to the different economic activities carried out in other states of the country, which are not significant in Morelos, for example, the industry.

Currently, the $\mathrm{CH}_{4}$ emissions from the landfills are not recovered or treated and are consequently emitted into the atmosphere, augmenting the GHG emissions. For this reason, according to several studies, the recovery and use of these emissions as fuel could be promoted to mitigate the effect of their release [31]-[34]. Also the use of a biologically-active landfill cover soils (biocovers) can serve as option to minimize landfill methane emissions [35].

In controlled landfills, the process of burying and compacting waste and regularly covering deposits with a low-permeability material creates an internal environment that favours $\mathrm{CH}_{4}$-producing bacteria. As with any ecological system, the optimum conditions of temperature, moisture, and nutrient source (i.e., organic waste) result in greater biochemical activity and hence greater generation of landfill gas. Waste sector emissions were estimated to account for 3\% - 5\% of the total global anthropogenic emissions in 2005 [36]. In a study performed by the US Environmental Protection Agency, the worldwide contribution of MSW for the year 2005 was estimated to be 750 mega tons (Mt) of $\mathrm{CO}_{2}$ eq, which was projected to increase by an additional $10 \mathrm{Mt}$ of $\mathrm{CO}_{2}$ eq by 2010 and $40 \mathrm{Mt}$ of $\mathrm{CO}_{2}$ eq by 2015 [37]. City governments are faced with several challenges in their efforts to streamline waste-management services and reduce GHG emissions related to MSW. A few of the pressing issues include the rapidly increasing quantities and diverse characteristics of waste, undesirable consequences of conventional methods of waste management, and failure to tap the resource value of waste.

Natural emissions are generated by biotic and abiotic processes, not related to human activities. The biotic sources are that produced in the ecosystems include the volatile organic compounds from phytoplankton in oceans, the $\mathrm{CO}_{2}$ liberating by the breathing of organisms, different gases derived from the microbial metabolism and the phytohormones liberation from plants, among others [38]. Regarding the abiotic emissions, some examples are the geothermal sources (volcano eruptions, fumaroles, geysers and other geothermal activities on the surface of the earth), lightning, biomass burning from forestry fires, etc. [39]. The biogenic emissions not were estimated in this study because the SWM it is an anthropogenic activity.

In Mexico, the current infrastructure for waste management is insufficient. Optimal waste management is not achieved, so promoting the reuse, collection and recycling of waste is a necessary action. In Mexico, the organic material component of MSW is 52\% [22], so there is considerable potential for reducing emissions, which are estimated as 16.6 to 18.7 million tons $\mathrm{CO}_{2}$ eq by 2020 mainly by composting treatments [11].

\section{Conclusions}

The MSW data collected from 1998 to 2012 reveal an increase in the amount of waste generated in Mexico and in Morelos that could be related to a modification in consumption patterns, which have been influenced by urbanization and an increase in the population and GDP. As observed in this study, more detailed MSW composition studies at both the local (each municipality) and regional levels are required because the existing statistics are of low quality and are most likely misestimated or nonexistent. In Morelos, the MSW collection services cover $90.7 \%$ of the population, but the lack of adequate technical expertise in the municipalities makes the management inefficient. Although the MSW contribution only represents $9.2 \%$ of the state GHG emissions, the realization of interdisciplinary research that involves social, economic and environmental considerations, as well as the population and municipal authorities' participation, are necessary to improve MSW management and generate mitigation strategies.

Recycling, waste separation, reuse, waste containment and creation of collection centres are identified as actions with great potential for the abatement of waste-related $\mathrm{CO}_{2}$ eq emission, in conjunction with strategies as 
composting the organic fraction or the recovery and use of the $\mathrm{CH}_{4}$ produced in landfills as fuel, can help to reduce the effect of MSW on the total GHG emissions of Mexico and Morelos. Additionally, the development of mechanisms and regulations that make organisations jointly responsible for managing the waste that they generate, are necessary, as is strengthening education and raising awareness about the importance of reducing the generation of waste and increasing the capture and use of $\mathrm{CH}_{4}$ for electrical power-generation campaigns. The use of landfill gas, recycling and composting offers solutions to various problems facing the country. To achieve sustainable use of waste, improved social participation through education and awareness campaigns and better collection systems under uniform criteria for waste management are required throughout the country. Adequate funding could help make the project self-sustaining.

\section{Acknowledgements}

This research was funded via sectorial funds from SEMARNAT-CONACyT, grant no. 108384.

\section{References}

[1] Ojeda-Benitez, S. and Beraud-Lozano, J.L. (2003) The Municipal Solid Waste Cycle in Mexico: Final Disposal. Resources, Conservation and Recycling, 39, 239-250. http://dx.doi.org/10.1016/S0921-3449(03)00030-2

[2] Buenrostro, O., Bocco, G. and Bernache, G. (2001) Urban Solid Waste Generation and Disposal in Mexico: A Case Study. Waste Management \& Research, 19, 169-176. http://dx.doi.org/10.1177/0734242X0101900208

[3] Tchobanoglous, G. (2009) Solid Waste Management, in Environmental Engineering: Environmental Health and Safety for Municipal Infrastructure, Land Use and Planning, and Industry. John Wiley \& Sons, Inc., Hoboken. http://dx.doi.org/10.1002/9780470432822.ch3

[4] Buenrostro, O., Bocco, G. and Vence, J. (2001) Forecasting Generation of Urban Solid Waste in Developing Countries-A Case Study in Mexico. Journal of the Air \& Waste Management Association, 51, 86-93. http://dx.doi.org/10.1080/10473289.2001.10464258

[5] Aguilar-Virgen, Q., Armijo-de Vega, C., Taboada-González, P.A. and Ojeda-Benítez, S. (2010) Municipal Solid Waste Generation and Characterization in Ensenada, México. The Open Waste Management Journal, 3, 140-145. http://dx.doi.org/10.2174/1875934301003010140

[6] González, C., Buenrostro, O., Marquez, L., Hernández, C., Moreno, E. and Robles, F. (2011) Effect of Solid Wastes Composition and Confinement Time on Methane Production in a Dump. Journal of Environmental Protection, 2, 1310-1316. http://dx.doi.org/10.4236/jep.2011.210151

[7] Intergovernmental Panel on Climate Change, Ed. (2014) Climate Change 2013: The Physical Science Basis: Working Group I Contribution to the Fifth Assessment Report of the Intergovernmental Panel on Climate Change. Cambridge University Press, Cambridge.

[8] INEGI (2005) National Institute of Geography and Statistics. Segundo Conteo de Población y Vivienda 2005. http://www.inegi.org.mx/sistemas/TabuladosBasicos/Default.aspx?c=10398\&s=est

[9] INEGI (2012) National Institute of Geography and Statistics. Perspectiva Estadística. Morelos. Aguascalientes. National Institute of Geography and Statistics, México. http://www.inegi.org.mx/prod_serv/contenidos/espanol/bvinegi/productos/integracion/estd_perspect/mor/Pers-mor.pdf

[10] SNIARN-SEMARNAT (2013) Sistema Nacional de Información Ambiental y de Recursos Naturales. Módulo de Consulta Temática, Dimensión Ambiental, Generación de Residuos Sólidos Urbanos 2010. http://dgeiawf.semarnat.gob.mx:8080/ibi_apps/WFServlet?IBIF_ex=D3_RSM01_04\&IBIC_user=dgeia_mce\&IBIC_p ass=dgeia_mce

[11] INECC-SEMARNAT (2012) México. Quinta Comunicación Nacional Ante la Convención Marco de las Naciones Unidas Sobre el Cambio Climático. México, D.F.

[12] IPCC (Intergovernmental Panel on Climate Change) (1996) Good Practice Guidance and Uncertainty Management in National Greenhouse Gas Inventories. Intergovernmental Panel on Climate Change, London.

[13] IPCC (Intergovernmental Panel on Climate Change) (1996) Guidelines for National Greenhouse Gas Inventories Reference Manual. Intergovernmental Panel on Climate Change, London.

[14] IPCC (Intergovernmental Panel onClimateChange) (1996) Directrices del Panel Intergubernamental de Cambio Climático para los Inventarios Nacionales de Gases de Efecto Invernadero, Versión Revisada en 1996. Libro de Trabajo para el Inventario de Gases de Efecto Invernadero. Vol. 2. London.

[15] Shekdar, A.V. (2009) Sustainable Solid Waste Management: An Integrated Approach for Asian Countries. Waste Management, 29, 1438-1448. http://dx.doi.org/10.1016/j.wasman.2008.08.025 
[16] Banco de México (2014) Serie Histórica Diaria del Tipo de Cambio Peso-Dólar. http://www.banxico.org.mx/SieInternet/consultarDirectorioInternetAction.do?accion=consultarCuadro\&idCuadro=CF 373\&sector $=6 \&$ locale $=$ es

[17] UNEP (2010) Framework of Global Partnership on Waste Management, Note by the Secretariat. http://www.unep.or.jp/Ietc/SPC/news-nov10/3_FrameworkOfGPWM.pdf

[18] CEAMA Comisión Estatal de Agua y Medio Ambiente (2007) Residuos Sólidos. http://www.ceamamorelos.gob.mx/secciones/ambiente/residuos_solidos.html

[19] LGPGIR (2007) Ley General para la Prevención y Gestión Integral de los Residuos. Última Reforma Publicada, Secretaría del Medio Ambiente y Recursos Naturales. Diario Oficial de la Federación, 19 dejunio de 2007.

[20] INEGI (2014) National Institute of Geography and Statistics. Estadística, Medio Ambiente. Asentamientos y Actividades Humanas. http://www3.inegi.org.mx/sistemas/temas/default.aspx?s=est\&c=21385

[21] Faccio, M., Persona, A. and Zanin, G. (2011) Waste Collection Multi Objective Model with Real Time Traceability Data. Waste Management, 31, 2391-2405. http://dx.doi.org/10.1016/j.wasman.2011.07.005

[22] SNIARN-SEMARNAT (2013) Capítulo 7. Residuos. Informe de la Situación del Medio Ambiente en México. Edición 2012, Compendio de Estadísticas Ambientales Indicadores Clave y de Desempeño Ambiental. http://app1.semarnat.gob.mx/dgeia/informe_12/pdf/Informe_2012.pdf

[23] DOF (2004) NOM-083-SEMARNAT-2003. Especificaciones de protección ambiental para la selección del sitio, diseño, construcción, operación, monitoreo, clausura y obras complementarias de un sitio de disposición final de residuos sólidos urbanos y de manejo especial.

[24] El-Fadel, M., Findikakis, A.N. and Leckie, J.O. (1997) Environmental Impacts of Solid Waste Landfilling. Journal of Environmental Management, 50, 1-25. http://dx.doi.org/10.1006/jema.1995.0131

[25] Sharholy, M., Ahmad, K., Mahmood, G. and Trivedi, R.C. (2008) Municipal Solid Waste Management in Indian Cities-A Review. Waste Management, 28, 459-467. http://dx.doi.org/10.1016/j.wasman.2007.02.008

[26] Guerrero, L.A., Maas, G. and Hogland, W. (2013) Solid Waste Management Challenges for Cities in Developing Countries. Waste Management, 33, 220-232. http://dx.doi.org/10.1016/j.wasman.2012.09.008

[27] Gobierno del Estado de Morelos (2008) Reglamento de la Ley de Residuos Sólidos para el Estado de Morelos. Periódico Oficial “Tierra y Libertad” 4596. 29 defebrero de 2008.

[28] Gobierno del Estado de Morelos (2010) Programa de Prevención y Gestión Integral de Residuos Sólidos Urbanos y de Manejo Especial del Estado de Morelos. Periódico Oficial “Tierra y Libertad” 4822. 21 de julio de 2010.

[29] Gobierno del Estado de Morelos (2011) Ley de Residuos Sólidos para el Estado de Morelos. Periódico Oficial “Tierra y Libertad” 4561 Sección Segunda. 17 de octubre de 2007.

[30] Quiroz-Castañeda, R.E., Sánchez-Salinas, E., Castrejón-Godínez, M.L. and Ortiz-Hernández, M.L. (2013) Greenhouse Gas Emissions in the State of Morelos, Mexico: A First Approximation for Establishing Mitigation Strategies. Journal of the Air \& Waste Management Association, 63, 1298-1312. http://dx.doi.org/10.1080/10962247.2013.822839

[31] Bogner, J., Pipatti, R., Hashimoto, S., Diaz, C., Mareckova, K., Diaz, L. and Gregory, R. (2008) Mitigation of Global Greenhouse Gas Emissions from Waste: Conclusions and Strategies from the Intergovernmental Panel on Climate Change (IPCC) Fourth Assessment Report. Working Group III (Mitigation). Waste Management \& Research, 26, 1132. http://dx.doi.org/10.1177/0734242X07088433

[32] Consonni, S., Giugliano, M. and Grosso, M. (2005) Alternative Strategies for Energy Recovery from Municipal Solid Waste: Part B: Emission and Cost Estimates. Waste Management, 25, 137-148. http://dx.doi.org/10.1016/j.wasman.2004.09.006

[33] Huber-Humer, M., Gebert, J. and Hilger, H. (2008) Biotic Systems to Mitigate Landfill Methane Emissions. Waste Management \& Research, 26, 33-46. http://dx.doi.org/10.1177/0734242X07087977

[34] Lou, X.F. and Nair, J. (2009) The Impact of Landfilling and Composting on Greenhouse Gas Emissions-A Review. Bioresource Technology, 100, 3792-3798. http://dx.doi.org/10.1016/j.biortech.2008.12.006

[35] Stern, J.C., Chanton, J., Abichou, T., Powelson, D., Yuan, L., Escoriza, S. and Bogner, J. (2007) Use of a Biologically Active Cover to Reduce Landfill Methane Emissions and Enhance Methane Oxidation. Waste Management, 27, 12481258. http://dx.doi.org/10.1016/j.wasman.2006.07.018

[36] Bogner, J., Abdelrafie Ahmed, M., Diaz, C., Faaij, A., Gao, Q., Hashimoto, S., Mareckova, K., Pipatti, R. and Zhang, T. (2007) Chapter 10. Waste Management. In: Metz, B., Davidson, O.R., Bosch, P.R., Dave, R. and Meyer, L.A., Eds., Climate Change 2007: Mitigation. Contribution of Working Group III to the Fourth Assessment Report of the Intergovernmental Panel on Climate Change, Cambridge University Press, Cambridge.

[37] USEPA (US Environmental Protection Agency) (2006) Solid Waste Management and Greenhouse Gases: A Life- Cycle Assessment of Emissions and Sinks. 3rd Edition, US EPA, Washington DC. 
[38] Velasco, E. and Bernabé, R.M. (2004) Emisiones Biogénicas. Instituto Nacional de Ecología (INE), México, D.F.

[39] Guenther, A., Geron, C., Pierce, T., Lamb, B., Harley, P. and Fall, R. (2000) Natural Emissions of Non-Methane Volatile Organic Compounds, Carbon Monoxide, and Oxides of Nitrogen from North America. Atmospheric Environment, 34, 2205-2230. http://dx.doi.org/10.1016/S1352-2310(99)00465-3 
Scientific Research Publishing (SCIRP) is one of the largest Open Access journal publishers. It is currently publishing more than 200 open access, online, peer-reviewed journals covering a wide range of academic disciplines. SCIRP serves the worldwide academic communities and contributes to the progress and application of science with its publication.

Other selected journals from SCIRP are listed as below. Submit your manuscript to us via either submit@scirp.org or Online Submission Portal.
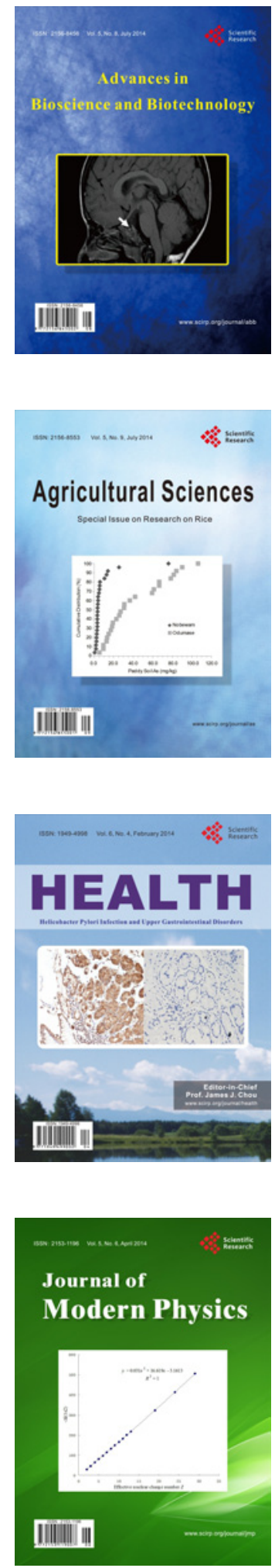
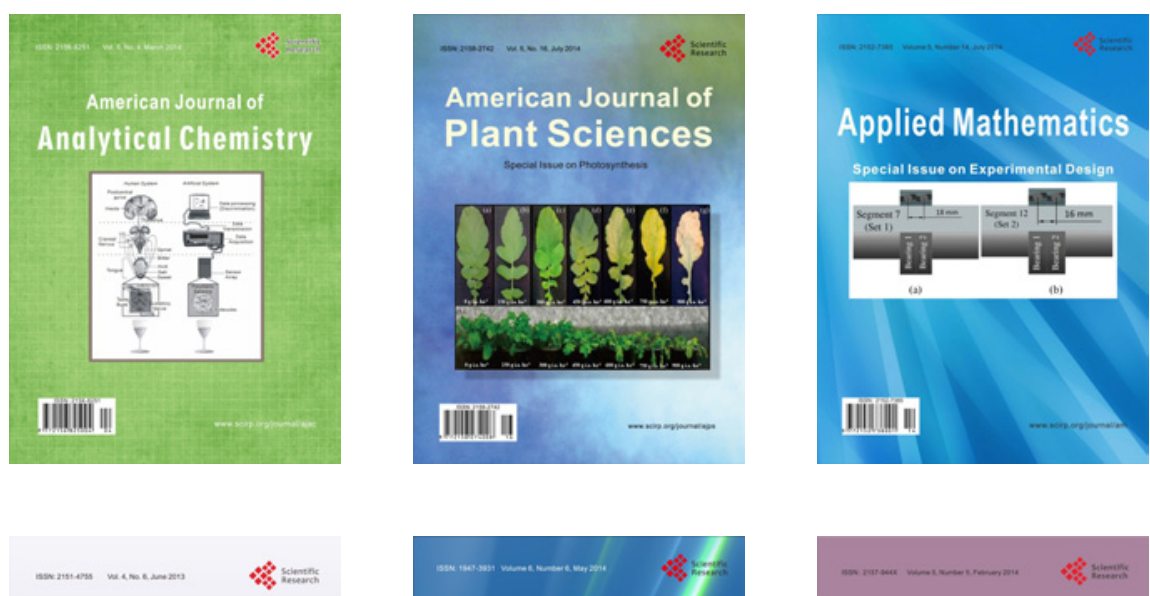

Creative Education
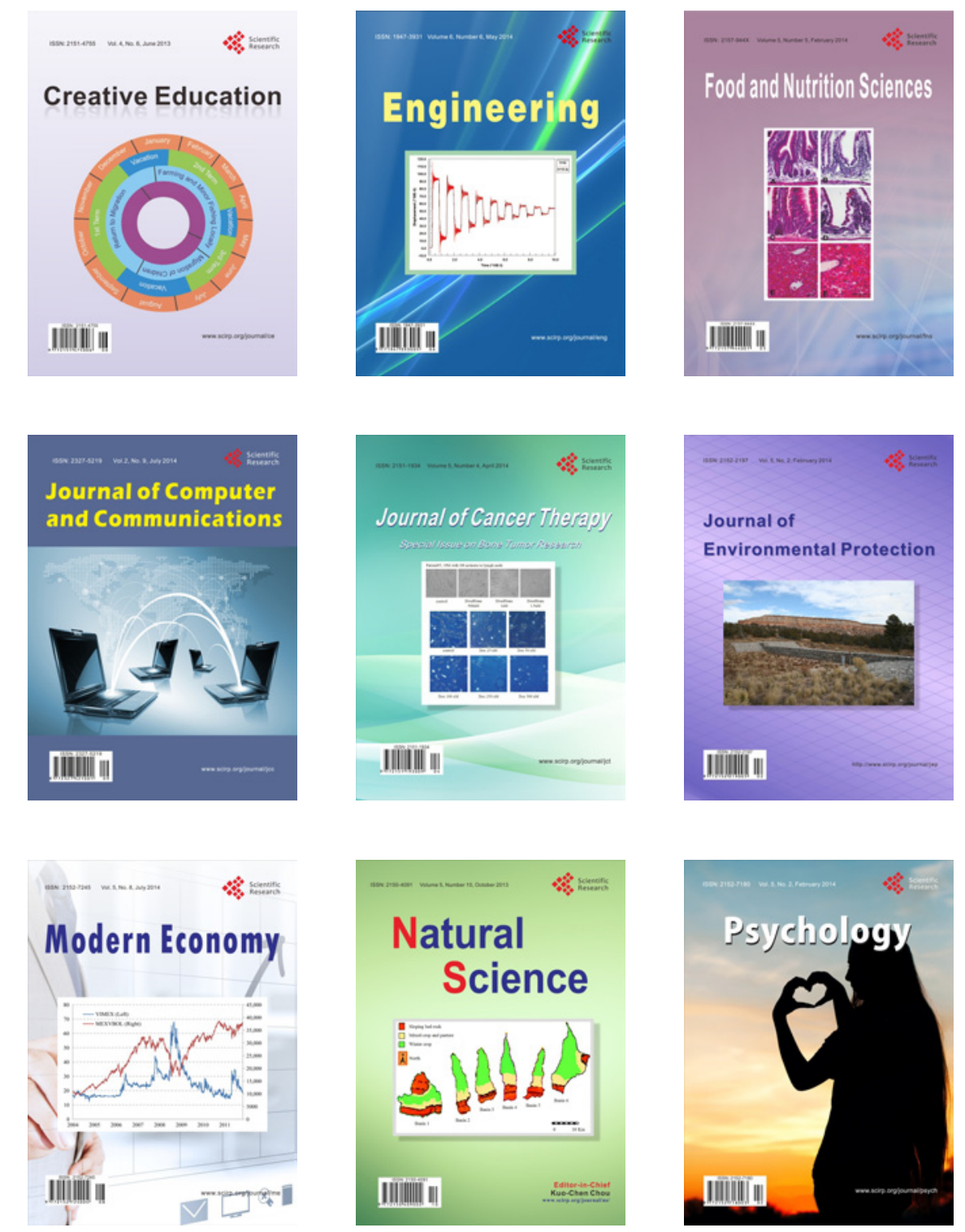